\title{
TATANIAGA IKAN KERAPU HIDUP DI KAWASAN SEGITIGA BATAM, TANJUNG PINANG DAN SINGAPURA (BaTaSi) : TINJAUAN ASPEK SOSIOLOGI
}

\author{
Sastrawidjaja, Riesti Triyanti dan Hikmah \\ Balai Besar Penelitian Sosial Ekonomi Kelautan dan Perikanan \\ Jl. KS. Tubun Petamburan VI Jakarta 10260 \\ Telp. (021) 53650162, Fax. (021)53650159 \\ e-mail: stwdjaja@yahoo.com \\ Diterima 15 Oktober 2012- Disetujui 27 November 2012
}

\begin{abstract}
ABSTRAK
Ikan kerapu hidup telah menjadi merek dagang (brand) dan ikon bagi masyarakat daerah sekitar kepulauan Batam, Tanjung Pinang dan Singapura (BaTaSi). Keunggulan ikan kerapu hidup adalah harganya yang sangat tinggi dan pangsa pasarnya tak terbatas. Pasar kerapu semakin meluas seiring meningkatnya minat penduduk Asia Timur untuk mengonsumsi ikan ini. Tingginya permintaan ekspor membuat konsumen luar negeri rela pergi ke sentra-sentra produksi kerapu di sejumlah perairan Indonesia terutama Kepulauan Batam dan Tanjung Pinang. Tulisan ini bertujuan untuk mengidentifikasi aspek sosiologi dari tataniaga pemasaran ikan kerapu hidup di Batam, Tanjungpinang dan Singapura (BaTaSi). Metode yang digunakan adalah studi kasus dengan analisis deskriptif kualitatif. Hasil Kajian menunjukkan bahwa dalam jalur tataniaga ikan kerapu di kawasan segitiga BaTaSi didominasi oleh dua etnis yaitu Tionghoa dan Melayu dengan strata sosial yang tinggi serta menggambarkan hubungan sosial diantara keduanya dalam hal jaringan sosial, perdagangan, dan kemitraan bisnis Ikan kerapu hidup. Adanya kepercayaan dan kebiasaan mengkonsumsi ikan kerapu saat Hari Raya Imlek menjadikan harga ikan kerapu jauh lebih tinggi dibandingkan hari-hari biasanya.
\end{abstract}

Kata kunci: : tataniaga, kerapu, sosiologi

Abstract : Commerce of Grouper Fish in the Triangle Batam, Tanjung Pinang and Singapore (BaTaSi): Aspects of Sociology Review. By: Sastrawidjaja, Riesti Triyanti and Hikmah.

Grouper life has become a trademark (brand) and an icon for the area around the islands of Batam, Tanjung Pinang and Singapore (BaTasi). Advantages live grouper is a very high price and its market share is almost unlimited. Grouper market expanding with increasing interest in the East Asian population to consume these fish. The high demand for exports made foreign consumers are willing to go to the grouper production centers in a number of Islands waters of Indonesia, especially Batam and Tanjung Pinang. The presence in a particular social strata provides the opportunity for consumers to enjoy a high taste in addition to providing opportunities to establish networks in the same environment and make it as a business opportunity. This paper aims to identify the sociological aspects of marketing trading system grouper in Batam, Tanjungpinang and Singapore (BaTaSi). The method used is a case study with a qualitative descriptive analysis. The study results showed that in lane grouper trading system in the triangle area BaTaSi is dominated by two ethnic tionghoa and malay with high social strata and describe social relations between them in terms of social networking, commerce, and business partnerships live groupers. The existence of the trust and grouper eating habits during the Chinese New Year makes grouper prices are much higher than usual days.

Keywords : trading system, grouper, sociology

\section{PENDAHULUAN}

Ikan kerapu hidup telah menjadi merek dagang (brand) masyarakat bagi daerah sekitar kepulauan Batam, Tanjung Pinang dan Singapura. Karena itu, aspek sosiologi tataniaga ikan kerapu hidup Batam, Tanjung Pinang dan Singapura (BaTaSi) menjadi sangat penting untuk melihat jalur perdagangan yang khas dan spesifik bagi etnis tertentu. Keunggulan ikan kerapu hidup adalah kemampuannya menjadi icon daerah karena harganya yang sangat mahal. Mendistribusikan ikan hidup agar mampu menjangkau konsumen memerlukan teknologi transportasi khusus, yaitu kapal yang dilengkapi sarana aerator. Sarana aerator yang terpasang di dalam kapal memungkinkan ikan selama dalam perjalanan berada pada situasi alami laut. Penggantian air laut berlangsung di sepanjang perjalanan sehingga ikan tetap terjaga dan beradaptasi dengan lingkungannya. Ikan kerapu hidup mempunyai pangsa pasar tersendiri. Konsumen ikan kerapu hidup diposisikan pada strata sosial dengan daya beli tinggi, lokasi penjualan di restoran kelas atas, perhotelan dan lokasi wisata mewah.

Masyarakat pesisir yang hidup di Kepulauan Riau sebagian besar bermata pencaharian sebagai nelayan dan pembudidaya ikan. Kegiatan utama nelayan adalah menangkap ikan dengan perahu dan menggunakan alat tangkap (pancing, jaring, dan bubu). Menurut Wolf (1966) dan Scot (1972), hubungan sosial antara nelayan yang hanya menangkap ikan dengan nelayan yang merangkap sebagai pembudidaya ikan dapat berbentuk 
vertikal (hierarkis), horizontal (pertemanan) dan diagonal (kakak-adik). Hubungan secara horizontal terjadi saat benih ikan kerapu yang berasal dari hasil tangkapan nelayan yang menangkap dengan bubu kemudian dibesarkan sesuai dengan kebutuhan pasar (> 500 gram). Ikan kerapu budidaya yang telah memenuhi ukuran pasar tersebut dijual ke pedagang (tauke) untuk di distribusikan ke pasar konsumen yang berada di luar Kepulauan Riau sehingga terjadi hubungan vertikal. Jaringan tataniaga ikan kerapu hidup meliputi antar pulau dan antar negara, karena konsumennya spesifik dan mempunyai karakteristik jejaring sosial sendiri. Fenomena hubungan sosial ini terlihat di dalam masyarakat pesisir sekitar Kepulauan Riau dari perilaku etnis Melayu dan Tionghoa di dalam menjalankan bisnis perikanan, khususnya ikan kerapu hidup.

Tujuan tulisan ini adalah untuk mengidentifikasi karakteristik tataniaga ikan kerapu hidup di Batam, Tanjungpinang dan Singapura (BaTaSi) ditinjau dari aspek sosiologi. Penelitian menggunakan metode studi kasus dengan pendalaman suatu unit atau individu (Neuman,1997). Metode pengumpulan data melalui survey dan pengamatan langsung oleh peneliti yang dilaksanakan pada bulan Juli 2012 di Kabupaten Bintan, Kota Tanjungpinang. Pendalaman informasi dikumpulkan melalui wawancara mendalam terhadap nelayan, pembudidaya, pedagang pengumpul lokal, eksportir, dan agen pengiriman (ekspedisi) di 3 lokasi yaitu Kecamatan Mantang, Bintan Timur dan Kijang, serta diskusi dengan stakeholder yaitu Dinas Kelautan dan Perikanan Kabupaten Bintan. Semua informasi dan data dikaji lebih dalam secara kualitatif, kemudian dituliskan secara deskriptif.

\section{Etnis Melayu dan Tionghoa dalam Perdagangan Ikan Kerapu}

Dua etnis yang bermukim di wilayah Kepulauan Riau, khususnya Kabupaten Bintan, Kota Tanjung Pinang dan Kota Batam, yaitu etnis Melayu Riau Kepulauan dan etnis Tionghoa, kedua etnis tersebut lama dan mempunyai jaringan sosial hingga kini dan terbentuklah jalinan perdagangan hasil perikanan. Kedua etnis tersebut melakukan pekerjaan yang berbeda dengan objek yang sama yaitu perikanan laut. Sumberdaya ikan yang berlimpah dengan beragam jenis dan spesies ikan (pelagis kecil, pelagis besar, demersal, udang dan kerang-kerangan) yang terdapat di wilayah Kepulauan Riau telah dijadikan sebagai sumber mata pencaharian utama bagi kedua etnis tersebut. Pembagian pekerjaan berbeda dari kedua etnis pada objek perikanan laut secara turun temurun, telah menciptakan hubungan sosial spesifik masyarakat pesisir yang memanfaatkan sumberdaya perikanan tersebut. Hubungan sosial spesifik dapat diketahui menurut sifat dari bentuk hubungan berdasarkan dari ukuran norma tanggung jawab, kepercayaan, keterampilan dan kejujuran. Adapun dasar pembentuk norma sosial dari etnis Melayu dan Tionghoa adalah kesepakatan-kesepakatan sosial antara kedua etnis tersebut. Tercermin dalam karakter sifat pekerjaan mereka. Oleh karena itu dari karakter sifat pekerjaan dapat dilihat bahwa etnis Melayu terbatas pada pekerjaan yang hanya melakukan penangkapan ikan dan pembudidayaan ikan kerapu yang menunjukkan sifat pekerjaannya lebih memusat pada alam. Ikan yang ditangkap telah disediakan oleh sumberdaya perairan disekitarnya, sedangkan etnis Tionghoa lebih menitikberatkan pada pekerjaan pemasaran ikan yang menunjukkan sifat pekerjaannya lebih meluas pada jaringan bisnis disektor perikanan. Aspek sosiologi dari tataniaga ikan kerapu hidup dilihat dari dua sudut pandang yaitu hubungan sosial dan jaringan sosial dua etnis yang ada di Kepulauan Riau.

\section{Aspek Hubungan Sosial}

Hubungan sosial dapat berupa hubungan timbal balik suatu komunitas yang dapat terbentuk berkelanjutan karena ada kebutuhan dasar bersama yang bersifat sosial utama (teknologi, ekonomi, norma) dan harus dipenuhi (Mubyarto, 1985).

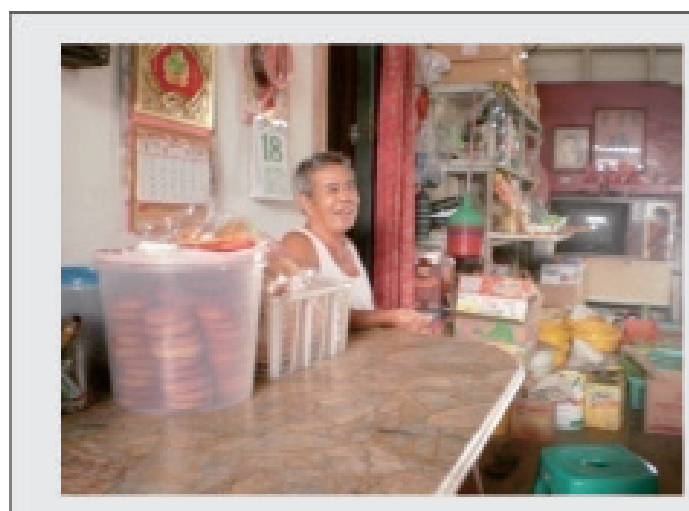

(1) Etnis Tionghoa

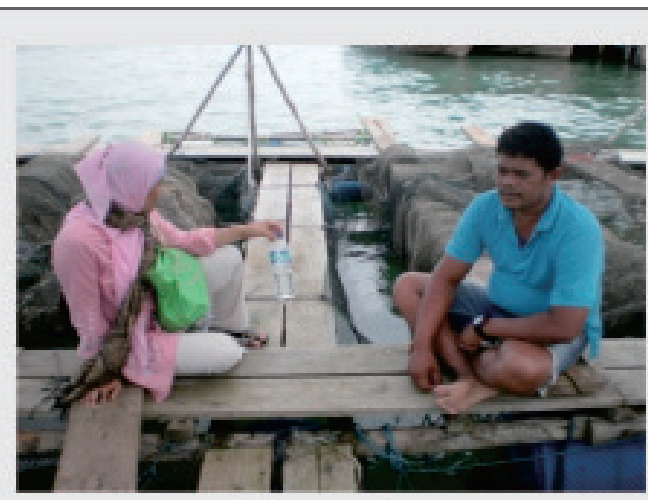

(2) Etnis Melayu

Gambar 1. Dua Etnis yang Berperan dalam Perdagangan Kerapu Hidup. 
Oleh sebab itu, hubungan merupakan kumpulan yang membentuk jaringan sebagai tempat interaksi antara satu pihak dengan pihak lainnya. Di dalam masyarakat pesisir, kebutuhan dasar bersama dapat dipenuhi dari sumberdaya perikanan dengan dibentuknya jaringan yang mempertemukan teknologi, ekonomi dan norma di tempat interaksi (tataniaga/ pemasaran/ distribusi/bisnis) antar etnis. Selain itu dalam Satria (2001), disebutkan bahwa kekuatan jaringan dipengaruhi oleh resiprositas, intensitas, dan durabilitas hubungan antarpihak.

Hubungan sosial dalam bentuk jaringan vertikal (hirarkis) adalah hubungan dua pihak yang berlangsung secara tidak seimbang karena satu pihak mempunyai dominasi yang lebih kuat dibanding pihak lain, atau terjadi hubungan patron-klien dari tataniaga/ pemasaran/distribusi serta bisnis. Tipe hubungan kedua etnis yang terjadi di Kepulauan Riau tersaji dalam Tabel 1.

Pada kenyataannya dalam suatu komunitas, termasuk komunitas nelayan dan pembudidaya ikan kerapu di Kepualauan Riau memiliki tiga bentuk hubungan yang saling tumpang tindih dan bervariasi, serta bentuk yang satu tidak dapat secara tegas dipisahkan dari bentuk lainnya (Rudiatin, 1997). Hal ini jelas terlihat di dalam masyarakat bahwa jaringan sosial merupakan salah satu bentuk strategi nelayan dan pembudidaya kerapu hidup di dalam menghadapi lingkungan pekerjaannya yang tidak menentu (Kusnadi, 2000).

\section{Aspek Jaringan Sosial dan Perdagangan}

Pola dari interaksi yang sistematik antara dua orang atau lebih yang terjadi secara teratur dan berulang kali dengan pola yang sama disebut sebagai hubungan sosial (Boissevain, 1978). Beberapa tipe hubungan sosial akan membentuk jaringan sosial. Jaringan sosial terbentuk dalam masyarakat karena pada dasarnya manusia tidak dapat berhubungan dengan semua manusia yang ada. Hubungan selalu terbatas pada sejumlah orang tertentu. Setiap orang belajar dari pengalamannya untuk masingmasing memilih dan mengembangkan hubunganhubungan sosial yang terbatas jumlahnya dibandingkan dengan jumlah rangkaian hubungan sosial yang tersedia, disesuaikan dengan kebutuhan-kebutuhan yang ada pada individu yang bersangkutan sehingga dalam usaha peningkatan taraf hidup juga tidak menggunakan semua hubungan sosial yang dimilikinya (Agusyanto, 2007).

Jaringan sosial di dalam masyarakat pesisir Kepulauan Riau dalam kasus perikanan kerapu, menggambarkan suatu hubungan sosial yang sedang terjadi antara pembudidaya ikan kerapu dengan pedagang ikan kerapu, sehingga lebih menunjukkan proses daripada bentuk.

Tabel 1. Hubungan Sosial Kedua Etnis di Kepulauan Riau.

\begin{tabular}{|c|c|c|c|}
\hline No. & Tipe Hubungan Sosial & Etnis Melayu & Etnis Tionghoa \\
\hline 1. & Hubungan Vertikal & $\begin{array}{l}\text { - Berprofesi sebagai nelayan dan } \\
\text { pembudidaya ikan kerapu di } \\
\text { sekitar tempat tinggalnya } \\
\text { - Jumlah pelaku banyak } \\
\text { - Volume produksi kecil } \\
\text { - Sebagai client }\end{array}$ & $\begin{array}{l}\text { - Berprofesi sebagai pedagang } \\
\text { pengumpul besar di Kepulauan } \\
\text { Riau } \\
\text { - Jumlah pelaku terbatas namun } \\
\text { terorganisir dengan baik } \\
\text { - Volume penjualan banyak } \\
\text { - Sebagai patron }\end{array}$ \\
\hline 2. & Hubungan Diagonal & $\begin{array}{l}\text { - Jaringan informasi pasar dan } \\
\text { penampungan sementara } \\
\text { dipusatkan di suatu tempat } \\
\text { secara temporal } \\
\text { - Tidak mempunyai bargaining } \\
\text { position yang kuat dalam jumlah } \\
\text { besar dan jangka panjang }\end{array}$ & $\begin{array}{l}\text { - Bertindak sebagai pedagang } \\
\text { pengumpul dan pembeli namun } \\
\text { mempunyai nilai jual yang tinggi } \\
\text { dalam hal volume dan jangka } \\
\text { waktu yang panjang } \\
\text { - Menguasai pasar kerapu diluar } \\
\text { Kepulauan Riau bahkan untuk } \\
\text { ekspor }\end{array}$ \\
\hline 3. & Hubungan Horizontal & $\begin{array}{l}\text { - Mempercayakan ikan kerapu } \\
\text { miliknya kepada kelompok } \\
\text { etnisnya yang bertindak sebagai } \\
\text { pedagang pengumpul lokal untuk } \\
\text { dijual kepada etnis Tionghoa }\end{array}$ & $\begin{array}{l}\text { - Mempercayakan ikan kerapu } \\
\text { miliknya kepada kelompok } \\
\text { etnisnya yang bertindak sebagai } \\
\text { pedagang pengumpul besar } \\
\text { untuk dijual ke konsumen di } \\
\text { luar Kepulauan Riau }\end{array}$ \\
\hline
\end{tabular}

Sumber : Data Primer diolah, 2012 
Jalinan perdagangan pada masyarakat pesisir dapat dikenali melalui jaringan sosial yang terbentuk karena dapat menunjukkan tipe hubungan sosial yang memiliki ikatan (kekerabatan, ras, etnik, pertemanan, ketetanggaan, dan kepentingan tertentu). Komunitas masyarakat pesisir di Kepulauan Riau terbentuk dari hasil akulturasi budaya dari etnis Melayu dan Tionghoa. Kedua etnis masing-masing mempunyai elemen pembentuk yang bersifat saling berhubungan satu sama lain yaitu kebutuhan "saling berdagang" dan telah menjadi satu kesatuan utuh yang diikat oleh suatu jaringan sosial bisnis. Masing-masing etnis mempunyai jaringan sosial tersendiri dalam hubungan perdagangan ikan kerapu.

Jaringan bisnis yang terjalin dalam etnis Tionghoa lebih kuat, lebih besar dan lebih luas daripada etnis melayu. Etnis tionghoa di Kabupaten Tanjung Pinang lebih menguasai pasar luar kabupaten (Kota Batam) dan luar negeri (Singapura). Hal ini didasari oleh kepercayaan yang kuat sesama etnis Tionghoa. Etnis Melayu cenderung memiliki jaringan bisnis yang terbatas pada pasar lokal dan hanya berfungsi sebagai pengumpul yang akhirnya disetorkan kepada etnis tionghoa untuk dipasarkan lebih lanjut.

\section{Aspek Hubungan Kemitraan Bisnis}

Kemitraan bisnis di bidang usaha perdagangan kerapu hidup terjadi di hulu hingga hilir yaitu pada pelaku usaha pembudidaya dengan pedagang. Harga ikan sebagai sumber pendapatan pembudidaya seringkali dikendalikan oleh para pemilik modal atau pedagang (tauke). Di Kabupaten Tanjung Pinang pedagang pengumpul besar berfungsi sebagai pemilik modal yang menyediakan keramba jaring apung, benih dan pakan, dengan perjanjian bila setelah di panen harus dijual ke pedagang pengumpul besar pemberi modal tersebut. Ada 23 KK (70\%) pembudidaya di Kabupaten Tanjung Pinang merupakan binaan dari pedagang pengumpul besar yang berfungsi juga sebagai eksportir. Hubungan kemitraan bisnis seperti ini disebut dengan pola patron-client.

Untuk kemitraan bisnis antara pedagang pengumpul besar dengan pedagang luar negeri (importir) sangat tergantung pada cara ikan kerapu hidup yang dapat dilihat melalui kegiatan pengangkutan atau tata niaga. Tataniaga merupakan proses kegiatan yang bertujuan menciptakan, menjaga dan meningkatkan nilai dan kegunaan tempat, waktu dan kepemilikan dari barang dan jasa. (Satria, 2001). Kegiatan pengangkutan dimulai dari penanganan ikan di tempat penampungan sementara yang dimiliki oleh pedagang pengmpul besar. Ikan kerapu hidup yang terkumpul di penampungan sementara tetap membutuhkan perhatian untuk menjaga kualitas ikan kerapu. Sistem pengangkutan ikan dari Tanjung Pinang ke Kota Batam dan ke luar negeri khususnya dari Singapura dan Hongkong sangat berbeda yang berpengaruh pada harga ikan kerapu yang disepakati. Untuk pengangkutan ke Kota Batam dan Singapura, biaya pengiriman ditanggung oleh pedagang pengumpul besar sedangkan pengiriman ke Hongkong, biaya pengiriman ditanggung oleh pembeli karena kapal pengangkut langsung dating dari Hongkong. Hubungan kemitraan bisnis seperti diatas disebut dengan pola bapak-anak dan tetap menguntungkan kedua belak pihak.

Kegiatan penjualan ikan kerapu hidup sebagai upaya pemenuhan kebutuhan konsumen terutama konsumen luar negeri, bertujuan untuk meningkatkan nilai tambah dan nilai guna. Peningkatan nilai tambah dan nilai guna terjadi karena adanya kesediaan konsumen untuk membayar lebih mahal terhadap ikan kerapu hidup. Perlakuan khusus yang diberikan sehingga mampu tetap hidup sampai di tempat tujuan. Ikan kerapu hidup mampu memberikan citarasa bagi konsumen dan meningkatkan status dan image sosial konsumen. Harga yang dibayarkan oleh konsumen dinilai pantas untuk diberikan kepada pemilik ikan kerapu hidup.

Tatacara hubungan kemitraan bisnis yang menjamin distribusi yang dilakukan oleh pelaku bisnis dari pembudidaya, pedagang pengumpul lokal dan agen pengiriman (ekspedisi) yang membentuk saling kepercayaan, maka jaringan sosial sistem distribusi ikan kerapu hidup yang dapat menjamin peningkatan nilai dan kegunaan bila didukung armada angkutan, sistem budidaya, handling dan mekanisme penampungan.

\section{Armada Angkutan}

Armada angkutan dalam sistem distribusi adalah sarana transportasi yang digunakan untuk memindahkan ikan kerapu hidup dari nelayan hingga ke penampung lokal, yang selanjutnya dikumpulkan pada pembudidaya. Armada angkutan yang melayani penampung lokal masih menggunakan perahu nelayan tradisional yang diisi air agar ikan kerapu tetap hidup. Pada saat ikan telah terkumpul di pedagang pengumpul kecil dengan menggunakan kapal yang dilengkapi aerator ikan kerapu hidup dibawa ke pedagang pengumpul besar yang diatur oleh agen pengiriman. Selama volume ikan kerapu hidup belum mencapai jumlah yang cukup untuk dibawa ke agen pengiriman, ikan kerapu hidup tersebut dibudidayakan oleh pedagang pengumpul kecil.

Pemasaran ikan kerapu hidup ke luar negeri, salah satunya adalah ke Singapura untuk dijual ke Pasar Jurong Fish. Waktu pengiriman ikan bergantung kepada permintaan dari Singapura. Volume untuk tiap kali pengiriman minimal 2 ton. Ikan kerapu hidup yang akan dikirim ke Singapura tersebut diangkut dengan menggunakan perahu motor. Ikan disimpan dalam bak palkah atau dalam bak fibre glass (1). Selama dalam perjalanan diadakan sirkulasi air laut dengan menggunakan pompa air (3). Bak palkah pada perahu motor dirancang sedemikian rupa sehingga sirkulasi air dapat berjalan lancar (Gambar 2). 


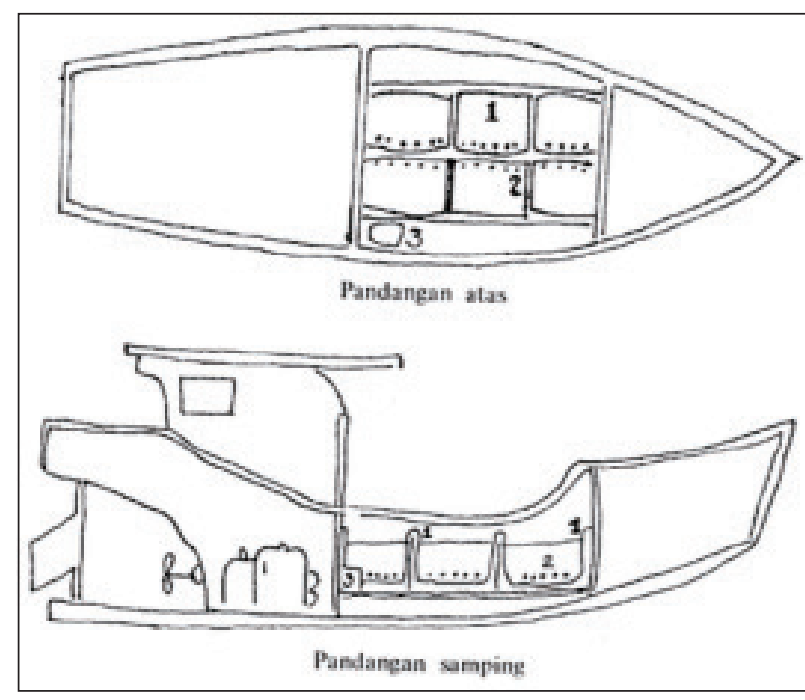

Gambar 2. Desain Kapal Pengangkut Ikan Kerapu Hidup (Sumber: Zuna, 1985).

Ikan kerapu hasil tangkapan nelayan disekitar Tanjung Pinang menggunakan sistem pengangkutan tradisional dengan kapal berukuran kecil, selanjutnya hasil tangkapan dijual ke pembudidaya untuk dibesarkan sehingga cukup untuk dijual atau dijual langsung ke pedagang pengumpul kecil maupun besar. Selain itu, seringkali nelayan menumpang untuk mengangkut peralatan penangkapan ikan pada kapal yang datang dari luar negeri. Pada kondisi seperti ini, nelayan akan membayar biaya kebutuhan pengangkutan peralatan dari ikan hasil tangkapan mereka. Kemitraan seperti diatas tetap berjalan dengan baik karena diantara mereka terjadi hubungan yang saling menguntungkan.

\section{Budidaya Ikan Kerapu}

Jalur distribusi ikan kerapu hidup dari pembudidaya dan nelayan akan mengalami dua jalur selanjutnya. Untuk jalur distribusi ke Singapura dilakukan oleh pedagang pengumpul kecil menggunakan agen pengiriman (ekspedisi), sedangkan jalur distribusi ke Hongkong dilakukan oleh pedagang pengumpul besar dan harus menunggu beberapa lama sampai jumlahnya mencukupi sesuai dengan pesanan pembeli dari Hongkong yaitu sebesar 15.000 ton sehingga diangkut menggunakan kapal yang dilengkapi aerator yang datang dari Hongkong.

Selama ikan kerapu masih berada di pedagang pengumpul besar, maka ditampung sementara dalam KJA khusus. Sebagian ikan kerapu yang dianggap belum mencapai ukuran pasar tetap dipelihara oleh pedagang pengumpul besar sampai ukurannya mencukupi untuk dijual yaitu seberat 500-1.000 gram. Untuk kegiatan budidaya ikan kerapu yang bersifat lanjutan ini, pedagang pengumpul besar harus mengeluarkan biaya tambahan yaitu dari pakan. Pakan yang digunakan adalah ikan rucah dengan harga rata-rata $\mathrm{Rp} 5.000 / \mathrm{kg}$ dengan ratarata pemberian pakan $6 \mathrm{~kg} / \mathrm{hari}$. Biaya tambahan untuk pakan yang ditanggung oleh pedagang pengumpul besar cukup tinggi untuk menunggu jumlah minimal ikan yang diminta oleh importir.

Pengangkutan kerapu hidup yang telah mencukupi kebutuhan pasar dilakukan dalam satu kwartal beberapa kali atau disesuaikan dengan kebutuhan permintaan konsumen yang ada di Batam, Singapura maupun Hongkong. Fungsi pemasaran (hilir) dilakukan oleh pedagang pengumpul besar, sedangkan fungsi usaha budidaya (hulu) dilakukan oleh pembudidaya ikan kerapu hidup yang berada disekitar Tanjungpinang dan Batam. Penggabungan dua fungsi usaha itu penting dilakukan agar fasilitas budidaya ikan kerapu dapat mendukung dan menjaga kepastian kesinambungan pelayanan pesanan (Lampe, 1989). Karena pembeli ikan kerapu hidup adalah konsumen yang berada di luar Kabupaten Tanjungpinang yang setiap waktu memesan ikan dan harus dilayani, maka model pedagang pengumpul besar menjadi sangat strategis untuk dapat menjalankan bisnis.

\section{Mekanisme Penampungan}

Ikan kerapu hidup tidak dapat dipertahankan apabila tidak ada mekanisme penampungan ikan yang baik sebelum ikan di distribusikan ke konsumen akhir. Mekanisme penampungan berhubungan dengan kemitraan bisnis yang akan menjamin berlangsungnya pendistribusian ikan kerapu hidup yang dilakukan oleh setiap pelaku bisnis sebagai lembaga tataniaga berupa pedagang pengumpul kecil (lokal), pedagang pengumpul besar (eksportir) dan agen pengiriman. Jaringan tataniaga perikanan di Kepulauan Riau yang bersifat spesifik telah berfungsi sebagai pelaku bisnis usaha ikan kerapu hidup, sehingga terbentuklah pembagian resiko usaha di dalam rantai tataniaganya. Resiko usaha yang ditanggung setiap mata rantai usaha tergantung dari bentuk mekanisme penampungan pembudidayaan ikan kerapu hidup. Bentuk mekanisme penampungan bersifat hubungan timbal balik antara nelayan dengan pembudidaya penampung yang didasarkan pada data mengenai ukuran ikan, lama penampungan, serta tingkat kematian ikan yang disepakati untuk menentukan kesesuaian harga ikan yang akan disetujui kedua belah pihak.

Agen pengiriman ikut berperan besar di dalam memperlancar pendistribusian ikan kerapu hidup di dalam sistem kelembagaan tataniaga perikanan di wilayah Kepulauan Riau, seperti di Kecamatan Kijang. Peranan yang mereka lakukan adalah menyediakan pelayanan jasa angkutan ikan menggunakan kapal pengangkut yang telah dilengkapi sistem sirkulasi air laut. Kapal-kapal pengangkut tersebut milik perusahaan lain yang mengikat kerjasama dengan agen pengiriman. Nelayan dan pembudidaya ikan kerapu yang tersebar diantara pulau-pulau yang mempunyai kemampuan 
produksi terbatas menggunakan jasa pengiriman untuk menjualkan ikannya ke pedagang pengumpul kecil dan pedagang pengumpul besar yang umumnya telah menjadi pelanggan.

Jaringan tataniaga yang spesifik tersebut membentuk pusat-pusat konsentrasi pembudidayaan ikan kerapu hidup. Nelayan pembudidaya dan pedagang pengumpul yang berada di desa nelayan dapat berfungsi sebagai pengumpul awal dan pemasok utama ikan kerapu hidup. Bentuk jalinan perdagangan di masyarakat pesisir dari sifat jaringan sosial yang membentuk hubungan sosial berdasarkan ikatan kekerabatan, ras, etnik, pertemanan, ketetanggaan, dan kepentingan tertentu kemudian diakui oleh masyarakat pesisir. Komunitas masyarakat pesisir di Kepulauan Riau adalah hasil akulturasi budaya antara etnis Melayu dengan Tionghoa. Kedua etnis tersebut masing-masing mempunyai elemen pembentuk berhubungan satu sama lain untuk memenuhi kebutuhan "saling berdagang" dan telah menjadi satu kesatuan utuh yang diikat oleh suatu jaringan sosial bisnis dan didalamnya tumbuh saling kepercayaan. Sebelum ikan kerapu hidup di distribusikan oleh pedagang pengumpul kecil ke pedagang pengumpul besar (eksportir) maka peran agen pengiriman dibutuhkan kedua belah pihak untuk menghubungkan masing-masing pihak yang terkait tentang informasi keberadaan dan kesiapan ikan kerapu hidup. Peran agen pengiriman menjadi penting, karena berfungsi sebagai penghubung antar etnis Melayu dengan Tionghoa yang dipercaya, dan pekerjaannya diakui bersama oleh kedua etnis tersebut di dalam bisnis perikanan.

\section{Informasi Harga dari Transaksi Jual Beli}

Informasi mengenai fluktuasi harga ikan kerapu hidup merupakan pengetahuan yang dimiliki oleh masing-masing pelaku bisnis sesuai dengan tingkatan jaringan tataniaga. Para nelayan yang pekerjaannya hanya menangkap ikan dan berada ditengah laut, sehingga mereka kurang sensitif terhadap informasi dan perkembangan harga ikan setiap hari. Kesepakatan nelayan dan pembudidaya kerapu dengan pedagang pengumpul kecil berdasarkan pada jenis ikan, jumlah ikan, dan kualitas kesegaran ikan. Nelayan maupun pembudidaya kerapu tidak mempunyai kekuatan apapun dalam menentukan harga. Pengendalian proses tawar menawar harga berada pada pedagang pengumpul kecil sehingga nelayan dan pembudidaya kerapu berada pada posisi tawar yang lemah. Kemudian antara pedagang pengumpul kecil dengan pedagang pengumpul besar terjadi proses tawar menawar yang dikendalikan oleh pedagang pengumpul besar. Adanya pola tataniaga yang bercirikan rantai tawar menawar yang berjenjang mengakibatkan posisi yang dibawah selalu tidak memiliki posisi bertahan yang kuat terhadap jenjang diatasnya. Pola tataniaga bercirikan rantai tawar menawar yang berjenjang oleh masyarakat antara etnis Melayu dengan Tionghoa dari aspek sosial kemasyarakatan pesisir dianggap wajar, karena kedua belah pihak merasa mempunyai kepastian terhadap ikan hidup mereka yang akan terus dibeli dan dibayar. Berdasarkan pola tataniaga, jalinan kerjasama bisnis ikan kerapu hidup disekitar wilayah Kepulauan Riau dapat berlangsung terus tanpa banyak menimbulkan kesenjangan sosial. Namun demikian beberapa responden menyatakan bahwa harga jual ikan kerapu hidup masih kurang transparan.

\section{KESIMPULAN}

Berdasarkan hasil penelitian, maka dapat ditarik kesimpulan sebagai berikut:

1. Tipe hubungan vertikal di daerah Kepulauan Riau sangat nyata bila dikaitkan antara etnis melayu dengan Tionghoa.

2. Kedua etnis di dalam menjalankan fungsi ekonomi (tataniaga, pemasaran, distribusi, bisnis) cenderung menjadikan elemen-elemen jaringan sosial bisnis tersebut sebagai dasar pembuatan keputusannya untuk menjalankan usaha perikanannya.

3. Kedua etnis mengikat hubungan sosial utama untuk dapat saling memenuhi kebutuhan hidup mereka dalam menjalin hubungan perdagangan hasil perikanan. Etnis Melayu yang terbatas pada pekerjaan yang tergantung pada alam sedangkan etnis Tionghoa lebih memberatkan pekerjaan sebagai pelaku pemasaran ikan.

4. Untuk menghindari kegagalan pemasaran, maka pelaku yang bergerak dibidang usaha ikan kerapu hidup dituntut memiliki berbagai persyaratan yang dapat menekan resiko kerugian usaha dari kerapu hidup.

5. Perbaikan sistem distribusi pemasaran menyangkut rekonstruksi sosial ekonomi yang mampu mensejajarkan posisi dari pihak-pihak yang terkait di dalam aktivitas tataniaga ikan kerapu hidup sehingga peningkatan kesejahteraan pembudidaya dapat dibangun melalui potensi lokal, yakni jaringan sosial yang terbentuk pada komunitas pembudidaya itu sendiri.

\section{DAFTAR PUSTAKA}

Agusyanto, R. 2007. Jaringan Sosial dalam Organisasi. Raja Grafindo Persada. Jakarta.

Boissevain, J. 1978. Friends of friends : Network, Manipulator and Coalition. Basil Blackwell. London and Worcester.

Kusnadi. 2000. Nelayan : Strategi Adaptasi dan jaringan Sosial. Humaniora Utama Press. Bandung.

Lampe, M. 1989. Strategi-strategi Adaptif yang Digunakan Nelayan Madura dalam Kehidupan Ekonomi Perikanan Lautnya. Tesis. Program 
Studi Antropologi Universitas Indonesia. Jakarta.

Mubyarto, S. L. 1985. Nelayan dan Kemiskinan : Studi Ekonomi Antropologi di Dua Desa Pantai. Yayasan Agro Ekonomi. Rajawali Press. Jakarta.

Neuman, W.L. 1997. Social Research Methods Qualitative and Quantitative Approaches. Nedham Heigts : Aviacom Company.

Rudiatin, E. 1997. Kepercayaan dan Kesetiaan : Bentuk dan Fungsi Jaringan Sosial Nelayan Muara Angke PAntai Utara Jakarta. Tesis. Pasca Sarjana Antropologi Universitas Indonesia. Depok.
Satria, A. 2001. Dinamika Modernisasi Perikanan Formasi Sosial dan Mobilitas Nelayan. Humaniora Utama Press. Bandung.

Scott, J. 1972. Patron Client Polities and Political Change in Southeast Asia. American Political Science Review, 66. 91-113 Pp.

Wolf, E. 1966. Kinship, Friendship and Patron Client Relation dalam Benton (Ed). The Social Anthropology of Complex Societies. Asociation of Applied Social Anthropology. London. 